\title{
Role Of Mass Media And Interpersonal Communication In Promoting Awareness About Woman Rights In Pakistan
}

\author{
Lubna Zaheer \\ \& \\ Amber Mubeen \\ Institute of Communication Studies \\ University of the Punjab, Lahore
}

\begin{abstract}
Women rights have always been a debatable issue in almost every society. Being a watchdog, media is expected to give voice to all members of the society regardless of their gender, background and ethnicity. Media can play a vigorous role to educating people about women-rights by addressing their concerns and anxieties. This study aims to investigate the role of mass media (i.e. television, newspapers and social media) and interpersonal communication in promoting awareness about woman rights in Pakistan. Using quantitative survey method with a sample of $\mathrm{N}=358$, results of One-way ANOVA show comparison among various types of media. The study figured out that mass media in Pakistan especially print media, play a positive role in promoting awareness about women rights. However, the role of interpersonal communication has been found more effective as compared to new and old media. The study also expresses that demographics play significant role to attaining the awareness about women rights.
\end{abstract}

Keywords: Women Rights, Mass Media, Television, Newspapers, Social Media, Interpersonal Communication, Socio-Economic Status.

$$
\begin{aligned}
& \text { تلخيص }
\end{aligned}
$$

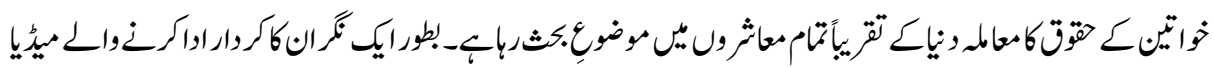

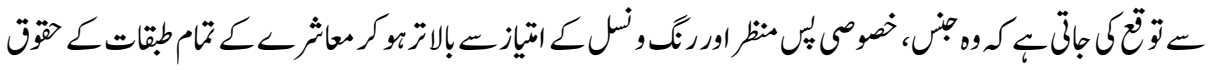

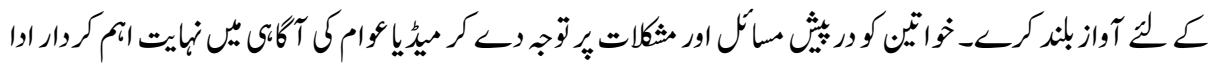

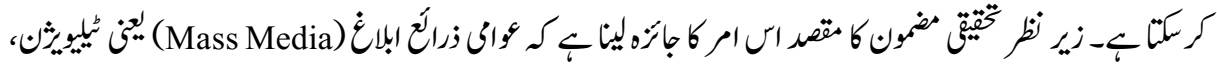

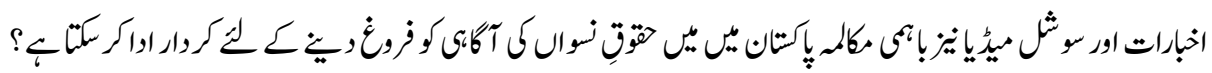

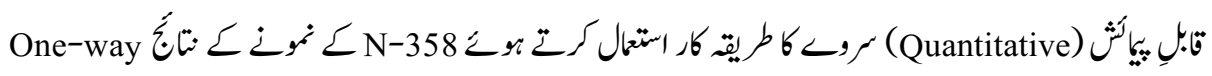

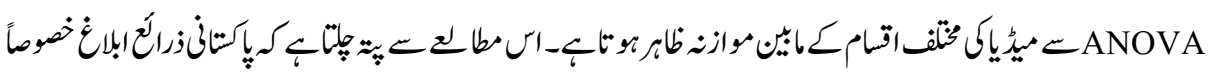

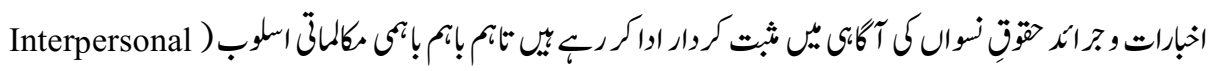




$$
\begin{aligned}
& \text { Communication }
\end{aligned}
$$

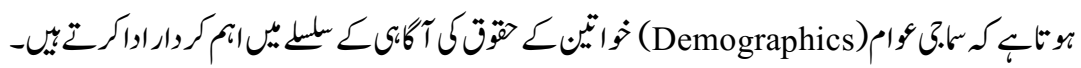

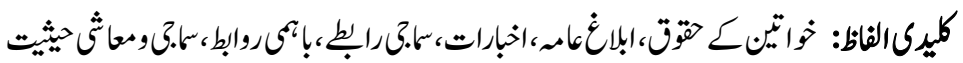

\section{Introduction}

Women rights have always been a profound area of deliberation for most of the nations. Different societies signify women rights according to their social, religious and political structures. It is believed that all people including marginalized groups require the protection of their rights in order to contribute in social, cultural, political, civic, and economic development of the country. Particularly, a fair gender treatment is an essential criterion to ensure a balanced face of any society. In this regard, there is a need that both males and females be treated and represented equally so that females could contribute towards creating a stable and comfortable environment to make certain the unceasing momentum of the society.

Women rights include all the social, economic and cultural liberties and choices that all people are entitled to. In many parts of the world women are denied to their basic rights even (Concern Worldwide, 2013). Although women rights are considered vital part of human rights schema (Ginsburg, 2007) and there are laws that guarantee equal rights to women in order to ensure their health care, education, social participation and economic development, however, despite all these rights, women are victims of harassment, discrimination and assault at offices and domestic level (Dunning et al., 2007). According to United Nations (2014), certain groups of women have to face added forms of discrimination based on their religion, nationality, age, marital status, disability and education level etc.

The fact remains that, being important segment of society, women play undeniable roles in different walks of life globally. Same is the situation in Pakistan where women are getting higher education and doing jobs even in those professions, which were specific for males in the past. It is a need of the hour that females must recognize their positive roles and placement in society to contribute effectively. As shared by Karl (1995) "women must be organized, articulate, persistent and representative to have an impact". Although, in Pakistani society women rights have become constant feature to much extent, even then females are prone to various types of difficulties and discriminations while working outside the homes or sometimes even staying at home. Moreover, when different segments of society start ignoring the discriminatory acts against women and pretend to be ignorant it results in the deprivation of women from their rights. In this scenario, women become more vulnerable and their voices are rebuked at relevant 
platform. According to Salinas (2015), this deprivation prevents women from full and equal participation in social, economic and political life". Sometimes, same situation is experienced in Pakistan.

In Pakistan almost 80 percent of women especially young females are unaware of their basic legal rights. Especially they are ignorant of their rights and privileges regarding marriage and divorce. Most of the time these rights are not even demanded (Concern Worldwide, 2013). Various organizations regularly monitor human rights issues in Pakistan and produce regular reports. Women rights are part of Islamic laws as well as a constitutional requirement. Governments in different regimes also have been taking legislative and administrative measures to protect women rights and empower them (Asia Report N, 2015). Regardless of all these, state of affairs is not satisfactory towards women.

Being a watchdog, mass media is expected to give voice to all members of society and educate people about their rights as well as responsibilities. Mass media is considered to be an important tool to propagate any agenda or policy and subsequently judged as an effective tool in perspective of gender representation (Malik \& Kiani, 2012). Similarly social media is considered important tool to enhancing women participations in various facets of their lives (Salem et al., 2011). It provides platform to women to discourse gender related issues that are under-reported in traditional media and convey their voice to policy-makers. However the impact of social media on policy makers is ambiguous thus far (The Guardian, 2015). But then again the importance of social media can't be unheeded and the example of Saudi Arabia may be quoted especially where women campaigned for their rights on social media and subsequently influenced the Saudi authorities (Altalebi, 2016).

Insofar as media's role towards women representation is concerned, it has become a global debate. It is often conversed that electronic and print media of world are continuously busy in promoting stereotypical image of women. Most of the time, physical beauty and apparent look of women are focused for the purpose of enhancing sale of the product(s). This kind of predisposed portrayal hinders the development of any society (Purnima, 2011). In Pakistan, media play its role to discourse and highlight human rights issues. Occasionally, it also affects policy and decision-making (Sial, 2009). However, it has been observed that the way Pakistani media portray the women, makes them more vulnerable and receptive to physical and symbolic violence (Asif, 2011). Moreover, women issues and problems are not highlighted adequately. One of the reasons is that most of the time, toplevel and executive positions in various media organizations are mostly held by men and consequently female representation is deficient (Pak Tribune, 2007).

Keeping in view the above-discoursed argument, this study examines the role of new (i.e. social media) and old media (i.e. print and TV) in Pakistan towards promoting awareness 
about women rights to general masses. Moreover, interpersonal communication (i.e. discussion with family, friends and/or colleagues etc.) has also been added into this discourse. The study also aims at considering the role of demographics (i.e. education and income) in getting awareness about women rights.

\section{Hypotheses}

Following hypotheses have been examined in this study:

1. Pakistani print media promotes more awareness among public about women rights as compared to social media

2. Pakistani TV Channels promote more awareness among public about women rights as compared to social media

3. Interpersonal communication is more effective in disseminating awareness about women rights as compared to mass media in Pakistan

4. Demographics have a significant relationship with awareness about women rights

\section{Theoretical Framework}

The study has been conducted within the theoretical structure of Uses and gratification theory (Katz, Blumer, \& Gurevitch, 1974) of mass communication. This theory is audience centered which puts emphasis on audience's selection and usage of different types of media for gratifying their different needs. The theory highlights the use of the media by different people. Being active audience, people can identify their needs and media, which is required to gratify those needs in a more contented way.

\section{Methodology}

In order to test the hypotheses of the study, survey method was used. The questionnaire was utilized for the purpose of data collection. The respondents $(\mathrm{N}=358)$ were selected from four different universities of Lahore namely Forman Christian College (A Chartered University), The University of Punjab, Superior University and the University of Lahore. In this regard, random sample technique was adopted. For data analysis, SPSS version 21 was used and One-way ANOVA with multiple comparisons of Tukey HSD was applied in order to explore the role of different types of media to promoting awareness about women rights.

\section{Results}

Results of One-way ANOVA show the statistical verification of this assumption that type of media has a significant relationship with the women rights awareness. Table 1 shows the output of ANOVA analysis and describes the statistical difference exists between the groups. The significance level $(p=.002)$ is below 0.05 . Hence, there is statistically significant difference in the mean of different types of media. Table 1 shows the 
descriptive results $(\mathrm{F}=5.025, \mathrm{p}=.002)$ of different types of media in creating awareness about women rights in public i.e. newspapers $(\mathrm{M}=1.9681, \mathrm{SD}=.57698)$, television $(\mathrm{M}=$ 1.9682, $\mathrm{SD}=.60304)$, social media $(\mathrm{M}=1.6835, \mathrm{SD}=.54993)$ and interpersonal communication $(\mathrm{M}=2.0000, \mathrm{SD}=.62361)$.

Table: 1

Descriptive (ANOVA) analysis of different types of media

\begin{tabular}{|c|c|c|c|c|c|c|c|c|c|c|}
\hline \multicolumn{9}{|c|}{ Descriptive } & & \\
\hline \multirow[b]{2}{*}{ Media } & \multirow[b]{2}{*}{$\mathrm{N}$} & \multirow[b]{2}{*}{ Mean } & \multirow{2}{*}{$\begin{array}{c}\text { Std. } \\
\text { Deviation }\end{array}$} & \multirow{2}{*}{$\begin{array}{l}\text { Std. } \\
\text { Error }\end{array}$} & \multicolumn{2}{|c|}{$\begin{array}{l}95 \% \text { Confidence } \\
\text { Interval for Mean }\end{array}$} & \multirow[b]{2}{*}{ Minimum } & \multirow[b]{2}{*}{ Maximum } & \multicolumn{2}{|c|}{ ANOVA } \\
\hline & & & & & $\begin{array}{l}\text { Lower } \\
\text { Bound }\end{array}$ & $\begin{array}{l}\text { Upper } \\
\text { Bound }\end{array}$ & & & $\mathrm{F}$ & Sig. \\
\hline Newspapers & 141 & 1.9681 & .57698 & .04859 & 1.8720 & 2.0642 & 1.00 & 3.00 & \multirow[t]{5}{*}{5.025} & \multirow[t]{5}{*}{.002} \\
\hline Television & 110 & 1.9682 & .60304 & .05750 & 1.8542 & 2.0821 & 1.00 & 3.00 & & \\
\hline Social Media & 79 & 1.6835 & .54993 & .06187 & 1.5604 & 1.8067 & 1.00 & 3.00 & & \\
\hline WOM $^{*}$ & 28 & 2.0000 & .62361 & .11785 & 1.7582 & 2.2418 & 1.00 & 3.00 & & \\
\hline Total & 358 & 1.9078 & .59281 & .03133 & 1.8462 & 1.9694 & 1.00 & 3.00 & & \\
\hline
\end{tabular}

Table: 1.1

Multiple Comparisons (ANOVA) analysis of different types of media

\begin{tabular}{|c|c|c|c|c|c|c|}
\hline \multicolumn{7}{|c|}{ Multiple Comparisons } \\
\hline \multirow{2}{*}{$\begin{array}{l}\text { (I) IP2 Which } \\
\text { type of media you } \\
\text { find more active } \\
\text { in promoting } \\
\text { awareness about } \\
\text { women issues }\end{array}$} & \multirow{2}{*}{$\begin{array}{l}\text { (J) IP2 Which } \\
\text { type of media } \\
\text { you find more } \\
\text { active in } \\
\text { promoting } \\
\text { awareness about } \\
\text { women issues }\end{array}$} & \multirow{2}{*}{$\begin{array}{c}\text { Mean } \\
\text { Difference } \\
(\mathrm{I}-\mathrm{J})\end{array}$} & \multirow[t]{2}{*}{$\begin{array}{c}\text { Std. } \\
\text { Error }\end{array}$} & \multirow[t]{2}{*}{ Sig. } & \multicolumn{2}{|c|}{$\begin{array}{l}\text { 95\% Confidence } \\
\text { Interval }\end{array}$} \\
\hline & & & & & $\begin{array}{l}\text { Lower } \\
\text { Bound }\end{array}$ & $\begin{array}{l}\text { Upper } \\
\text { Bound }\end{array}$ \\
\hline \multirow{3}{*}{ Newspapers } & Television & -.00010 & .07417 & 1.000 & -.1915 & .1914 \\
\hline & Social Media & $.28454^{*}$ & .08194 & .003 & .0730 & .4960 \\
\hline & WOM & -.03191 & .12063 & .994 & -.3433 & .2795 \\
\hline \multirow{3}{*}{ Television } & Newspapers & .00010 & .07417 & 1.000 & -.1914 & .1915 \\
\hline & Social Media & $.28464^{*}$ & .08598 & .006 & .0627 & .5066 \\
\hline & WOM & -.03182 & .12341 & .994 & -.3504 & .2867 \\
\hline \multirow{3}{*}{ Social Media } & Newspapers & $-.28454^{*}$ & .08194 & .003 & -.4960 & -.0730 \\
\hline & Television & $-.28464^{*}$ & .08598 & .006 & -.5066 & -.0627 \\
\hline & WOM & -.31646 & .12823 & .067 & -.6475 & .0145 \\
\hline \multirow{3}{*}{ WOM } & Newspapers & .03191 & .12063 & .994 & -.2795 & .3433 \\
\hline & Television & .03182 & .12341 & .994 & -.2867 & .3504 \\
\hline & Social Media & .31646 & .12823 & .067 & -.0145 & .6475 \\
\hline
\end{tabular}

* WOM stand for words of mouth, used for interpersonal communication 
170 Role of Mass Media and Interpersonal Communication in Promoting Awareness about Woman Rights in Pakistan

Multiple comparisons test shows as to which type of media is more successful in promoting awareness regarding women rights. A significant difference has been found between print media and social media and similarly between social media and electronic media.

ANOVA analysis indicates statistical difference $(\mathrm{p}=.003)$ between print and social media in terms of promoting awareness about women rights. Similarly, significant relationship $(\mathrm{p}=.006)$ has been found between television and social media. However, insignificant difference $(\mathrm{p}=1.000)$ has been found between television and newspapers as well as TV and WOM $(\mathrm{p}=.994)($ see Table 1.1).

Table 2 gives the results of One-way ANOVA in which level of women rights has been checked against academic qualification of the respondents. Results indicate that there is significant relationship between both variables. Table 2 shows output of ANOVA analysis and describes the statistical difference exists between the groups. The significance level is $0.000(\mathrm{p}=.000)$, which is below 0.05 . It means that there is statistically significant difference in the mean of various education groups. Data describes that education is an important variable that determines the level of women rights awareness amongst people. Value of mean varies in different categories i.e. $\mathrm{M}=1.5769$ for under matriculation, $\mathrm{M}=1.6500$ for Matric to Bachelors and $\mathrm{M}=2.1058$ for postgraduates and above. Results of ANOVA test indicate $(F=22.244, p=.000)$.

Table: 2

Descriptive (ANOVA) analysis of education

\begin{tabular}{|c|c|c|c|c|c|c|c|c|c|c|}
\hline \multicolumn{11}{|c|}{ Descriptive } \\
\hline & \multirow[b]{2}{*}{$\mathrm{N}$} & \multirow[b]{2}{*}{ Mean } & \multirow[b]{2}{*}{$\begin{array}{l}\text { Std. } \\
\text { Deviation }\end{array}$} & \multirow[b]{2}{*}{$\begin{array}{l}\text { Std. } \\
\text { Error }\end{array}$} & \multicolumn{2}{|c|}{$\begin{array}{l}95 \% \text { Confidence } \\
\text { Interval for Mean }\end{array}$} & \multirow[b]{2}{*}{ Minimum } & \multirow[b]{2}{*}{ Maximum } & \multicolumn{2}{|c|}{ ANOVA } \\
\hline & & & & & $\begin{array}{l}\text { Lower } \\
\text { Bound }\end{array}$ & $\begin{array}{l}\text { Upper } \\
\text { Bound }\end{array}$ & & & $\mathrm{F}$ & Sig. \\
\hline $\begin{array}{l}\text { Under } \\
\text { Matric }\end{array}$ & 60 & 1.5769 & .57210 & .07934 & 1.4176 & 1.7362 & 1.00 & 3.00 & 22.244 & .000 \\
\hline $\begin{array}{l}\text { Matric- } \\
\text { Bachelor }\end{array}$ & 90 & 1.6500 & .58756 & .06193 & 1.5269 & 1.7731 & 1.00 & 3.00 & & \\
\hline $\begin{array}{l}\text { Post- } \\
\text { grad- } \\
\text { Above }\end{array}$ & 208 & 2.1058 & .51861 & .03596 & 2.0349 & 2.1767 & 1.00 & 3.00 & & \\
\hline Total & 358 & 1.9078 & .59281 & .03133 & 1.8462 & 1.9694 & 1.00 & 3.00 & & \\
\hline
\end{tabular}


Table: 2.1

Multiple comparisons (ANOVA) analysis of education

\begin{tabular}{|c|c|c|c|c|c|c|}
\hline \multicolumn{7}{|c|}{$\begin{array}{c}\text { Multiple Comparisons } \\
\text { Tukey HSD }\end{array}$} \\
\hline \multirow{2}{*}{$\begin{array}{l}\text { (I) D3 } \\
\text { Education }\end{array}$} & \multirow{2}{*}{$\begin{array}{l}\text { (J) D3 } \\
\text { Education }\end{array}$} & \multirow{2}{*}{$\begin{array}{c}\text { Mean } \\
\text { Difference (I-J) }\end{array}$} & \multirow{2}{*}{$\begin{array}{l}\text { Std. } \\
\text { Error }\end{array}$} & \multirow[t]{2}{*}{ Sig. } & \multicolumn{2}{|c|}{$\begin{array}{c}\text { 95\% Confidence } \\
\text { Interval }\end{array}$} \\
\hline & & & & & $\begin{array}{l}\text { Lower } \\
\text { Bound }\end{array}$ & $\begin{array}{l}\text { Upper } \\
\text { Bound }\end{array}$ \\
\hline \multirow{2}{*}{$\begin{array}{l}\text { Under } \\
\text { Matriculation }\end{array}$} & $\begin{array}{l}\text { Matriculation- } \\
\text { Bachelor }\end{array}$ & -.07308 & .09512 & .869 & -.3186 & .1725 \\
\hline & $\begin{array}{l}\text { Post graduation } \\
\text { and Above }\end{array}$ & $-.52885^{*}$ & .08466 & .000 & -.7474 & -.3103 \\
\hline \multirow{2}{*}{$\begin{array}{l}\text { Matriculation } \\
\text {-Bachelor }\end{array}$} & $\begin{array}{l}\text { Under } \\
\text { Matriculation }\end{array}$ & .07308 & .09512 & .869 & -.1725 & .3186 \\
\hline & $\begin{array}{l}\text { Post graduation } \\
\text { and Above }\end{array}$ & $-.45577^{*}$ & .06890 & .000 & -.6336 & -.2779 \\
\hline \multirow{2}{*}{$\begin{array}{l}\text { Post- } \\
\text { graduation } \\
\text { and Above }\end{array}$} & $\begin{array}{l}\text { Under } \\
\text { Matriculation }\end{array}$ & $.52885^{*}$ & .08466 & .000 & .3103 & .7474 \\
\hline & $\begin{array}{l}\text { Matriculation- } \\
\text { Bachelor }\end{array}$ & $.45577^{*}$ & .06890 & .000 & .2779 & .6336 \\
\hline
\end{tabular}

Multiple comparisons test has been applied to the data collected from sample. Table 2.1 shows the difference between the groups. ANOVA analysis shows that there is statistical difference in relationship between awareness of women rights in under matriculation and post-graduation and above $(\mathrm{p}=.000)$, as well as matriculation-Bachelor and postgraduation and above $(p=.000)$. However, no significant difference has been found between under-matriculation and Matriculation-Bachelor $(p=.869)$.

\section{Table: 3}

\section{Descriptive (ANOVA) analysis of income}

\begin{tabular}{|c|c|c|c|c|c|c|c|c|c|c|}
\hline \multicolumn{11}{|c|}{ Descriptive } \\
\hline \multirow{2}{*}{$\begin{array}{l}\text { Income } \\
\text { (In Rs.) }\end{array}$} & \multirow[b]{2}{*}{$\mathrm{N}$} & \multirow[b]{2}{*}{ Mean } & \multirow[b]{2}{*}{$\begin{array}{c}\text { Std. } \\
\text { Deviation }\end{array}$} & \multirow[b]{2}{*}{$\begin{array}{l}\text { Std. } \\
\text { Error }\end{array}$} & \multicolumn{2}{|c|}{$\begin{array}{l}\text { 95\% Confidence } \\
\text { Interval for Mean }\end{array}$} & \multirow[b]{2}{*}{ Min. } & \multirow[b]{2}{*}{ Max. } & \multicolumn{2}{|c|}{ ANOVA } \\
\hline & & & & & $\begin{array}{l}\text { Lower } \\
\text { Bound }\end{array}$ & $\begin{array}{l}\text { Upper } \\
\text { Bound }\end{array}$ & & & $\mathrm{F}$ & Sig. \\
\hline $0-49000$ & 103 & 1.8738 & .60520 & .05963 & 1.7555 & 1.9921 & 1.00 & 3.00 & 3.857 & .010 \\
\hline $50000-99000$ & 83 & 1.8012 & .61456 & .06746 & 1.6670 & 1.9354 & 1.00 & 3.00 & & \\
\hline $100000-149000$ & 68 & 1.8456 & .54126 & .06564 & 1.7146 & 1.9766 & 1.00 & 3.00 & & \\
\hline $\begin{array}{l}150000 \text { and } \\
\text { above }\end{array}$ & 104 & 2.0673 & .57055 & .05595 & 1.9564 & 2.1783 & 1.00 & 3.00 & & \\
\hline Total & 358 & 1.9078 & .59281 & .03133 & 1.8462 & 1.9694 & 1.00 & 3.00 & & \\
\hline
\end{tabular}


172 Role of Mass Media and Interpersonal Communication in Promoting Awareness about Woman Rights in Pakistan

One-way ANOVA was applied to the data collected from sample of people belonged to different socio-economic backgrounds. Results show that socio-economic background has significant impact on the level of awareness about women rights. Table 2 shows that output of ANOVA analysis and describes that statistical difference exists between the groups. The significance level is $0.01(\mathrm{p}=.01)$, which is below 0.05 . Therefore there is statistically significant difference in the mean of different income groups. Thus, data describes that income level is another important variable, which determines the level of women rights awareness among people. Table (2) shows that there is difference between the mean value of categories with high and low income i.e. $\mathrm{M}=1.8738$ for respondents with 0 to 49000 income and $M=2.0673$ for respondents with income 150000 and above income. There is difference $(\mathrm{M}=.1935)$ in means of both categories. Results of ANOVA test indicate $(\mathrm{F}=3.857, \mathrm{p}=.010)$.

Table: 3.1

Multiple comparisons (ANOVA) analysis of income

\begin{tabular}{|c|c|c|c|c|c|c|}
\hline \multicolumn{7}{|c|}{$\begin{array}{c}\text { Multiple Comparisons } \\
\text { Tukey HSD }\end{array}$} \\
\hline \multirow{2}{*}{$\begin{array}{l}\text { (I) D4 Monthly } \\
\text { Income }\end{array}$} & \multirow{2}{*}{$\begin{array}{l}\text { (J) D4 Monthly } \\
\text { Income }\end{array}$} & \multirow{2}{*}{$\begin{array}{l}\text { Mean } \\
\text { Difference } \\
\text { (I-J) }\end{array}$} & \multirow{2}{*}{$\begin{array}{l}\text { Std. } \\
\text { Error }\end{array}$} & \multirow[t]{2}{*}{ Sig. } & \multicolumn{2}{|c|}{$\begin{array}{c}95 \% \text { Confidence } \\
\text { Interval }\end{array}$} \\
\hline & & & & & $\begin{array}{l}\text { Lower } \\
\text { Bound }\end{array}$ & $\begin{array}{l}\text { Upper } \\
\text { Bound }\end{array}$ \\
\hline \multirow{3}{*}{$0-49000$} & $50000-99000$ & .07258 & .08641 & .835 & -.1505 & .2956 \\
\hline & $100000-149000$ & .02820 & .09154 & .990 & -.2081 & .2645 \\
\hline & 150000 and above & -.19352 & .08144 & .084 & -.4037 & .0167 \\
\hline \multirow{3}{*}{$50000-99000$} & $0-49000$ & -.07258 & .08641 & .835 & -.2956 & .1505 \\
\hline & 100000-149000 & -.04438 & .09582 & .967 & -.2917 & .2030 \\
\hline & 150000 and above & $-.26610^{*}$ & .08622 & .012 & -.4887 & -.0435 \\
\hline \multirow{3}{*}{$100000-149000$} & $0-49000$ & -.02820 & .09154 & .990 & -.2645 & .2081 \\
\hline & $50000-99000$ & .04438 & .09582 & .967 & -.2030 & .2917 \\
\hline & 150000 and above & -.22172 & .09136 & .074 & -.4575 & .0141 \\
\hline \multirow{3}{*}{$\begin{array}{l}150000 \text { and } \\
\text { above }\end{array}$} & $0-49000$ & .19352 & .08144 & .084 & -.0167 & .4037 \\
\hline & $50000-99000$ & $.26610^{*}$ & .08622 & .012 & .0435 & .4887 \\
\hline & $100000-149000$ & .22172 & .09136 & .074 & -.0141 & .4575 \\
\hline
\end{tabular}

Multiple comparisons test has been applied to the data collected from sample, which shows the difference between the groups. ANOVA analysis shows that there is statistical difference among relationship between awareness of women rights in people with 5000099000 income and 150000 and above income $(\mathrm{p}=.01)$. There is no significant difference between people with income between 0-49000 and 50000-99000 $(\mathrm{p}=.835)$, as well as 0 49000 and $100000-149000(\mathrm{p}=.990)$. The results show that there is significant difference between low-income and high-income groups about the awareness of women rights (see Table 3.1). 
H1: Pakistani newspapers promotes more awareness among public about women rights as compared to social media

Multiple comparisons show statistically significant difference $(p=.003)$ between both categories. Mean value of newspapers $(\mathrm{M}=1.9681, \mathrm{SD}=.57698)$ has been found higher than social media $(\mathrm{M}=1.6835, \mathrm{SD}=.54993)$, which means that print media brings more awareness about women rights as compared to social media. Results of ANOVA indicate that $\mathrm{F}=5.025, \mathrm{P}=.002$ (see Table $1 \& 1.1$ ).

\section{H2: Pakistani TV Channels promote more awareness among public about women rights as compared to social media}

Multiple comparisons show statistically significant difference $(p=.006)$ between both categories. Mean value of television $(\mathrm{M}=1.9682, \mathrm{SD}=.60304)$ has been found higher than social media $(\mathrm{M}=1.6835, \mathrm{SD}=.54993)$, which means that television brings more awareness about women rights as compared to social media (see Table $1 \& 1.1$ ).

H3: Interpersonal communication is more effective in disseminating awareness about women rights as compared to mass media in Pakistan

Descriptive results of different types of media show that mean value of Interpersonal communication $(\mathrm{M}=2.0000, \mathrm{SD}=.62361)$ is higher as compared to newspapers $(\mathrm{M}=$ $1.9681, \mathrm{SD}=.57698)$, television $(\mathrm{M}=1.9682, \mathrm{SD}=.60304)$ and social media $(\mathrm{M}=1.6835$, $\mathrm{SD}=.54993)$. It means that interpersonal communication is more effective in generating awareness about women rights as compared to other mediums (see Table $1 \& 1.1$ ).

H4: Demographics has a significant relationship with awareness about women rights

It has been found that education is another important variable to determine the level of women rights awareness among people. Multiple comparisons show statistically significant relationship $(\mathrm{p}=.000)$ among awareness of women rights in under matriculation $(M=1.5769)$, and up to bachelors $(M=1.6500)$ and post-graduation and above students $(\mathrm{M}=2.1058)$. It means that people with low level of education are less aware of women rights as compared to the people with high-level of education. Results of ANOVA test show that $\mathrm{F}=22.244, \mathrm{p}=.000$ (see Table $2 \& 2.1$ ).

Similarly, results have shown that socioeconomic status (i.e. income) is one of the significant variables in determining the level of women right awareness amongst people. Table 3 shows significant difference $(M=.19352)$ in mean value of high-income $(M=$ 
174 Role of Mass Media and Interpersonal Communication in Promoting Awareness about Woman

Rights in Pakistan

2.0673) and low-income $(\mathrm{M}=1.8738)$ categories. It means that people with low-income has less women rights awareness as compared to high-income people. Results of ANOVA test indicate $\mathrm{F}=3.857, \mathrm{P}=.010$ (see Table 3 \& 3.1).

\section{Conclusions}

Findings of the study show that these three mediums (i.e. television, newspapers and social media) play important role in promoting awareness regarding women rights. However traditional media (i.e. TV and newspapers) has been found to play more important role in creating public awareness about women rights as compared to new media (i.e. social media). Exceptionally, interpersonal communication has been found to be more functional to promoting awareness about women rights compared to traditional and new media.

Thus according to our results, Pakistani people consider interpersonal communication more vigorous to addressing women issues and to educating people about women rights. It is also found that although, globally, social media is considered one of important avenues for creating awareness among masses about certain issue, however, results of the study indicate that in Pakistani society social media is not an effective tool as compared to traditional media. Furthermore, socioeconomic status has been discovered one of significant variables to determine the level of awareness about women rights in public. Thus it has been learned that people with high-level of education and/or income are more aware of the women rights compared to the people with low-level of education and/or income.

At the end, it may be said that media play an important role in creating awareness about women rights and awareness may be promoted among general public through its content and subsequently attitude of people may be transformed gradually towards women rights and their status in the society. It is also deduced that even in the presence of new media, traditional media has its own importance in Pakistani society. Thus all types of media along with interpersonal communication may be utilized to promote awareness among people of Pakistan about the women rights.

\section{References}

Altalebi, L. (2016). Saudis Take to Social Media with Campaign Supporting Women's Right to Drive in the kingdom.

Asif, M. (2011). Violence against Women in Pakistan: Role of Police and Media. Social Sciences Review of Pakistan, 13. 
Asia Report $\mathrm{N}^{\circ}$ 265. (2015). Women, Violence and Conflict in Pakistan, International Crisis Group.

Concern WorldWide (2013). Women's Rights: How can we ensure that all women have equal access to their rights? Global concern classroom, U.S.A.

Dunning, C., Rosenfeld, D., Mardirossian, T., Langston, D. \& Lawler, A. (2007). Women's Rights Guide. Bernard Koteen Office of Public Interest Advising Harvard Law School.

Ginsburg, B. R. (2007). Tribute: The Legacy Of Ruth Bader Ginsburg And WRP Staff. American Civil Liberties Union. Retrieved from https://www.aclu.org/tributelegacy-ruth-bader-ginsburg-and-wrp-staff

Karl, M. (1995). Women and Empowerment: Participation and Decision Making. Taylor \& Francis, 10.

Katz, E., Blumer, J. G., \& Gurevitch, M. (1974). Utilization of Mass Communication by the Individual. In J. G. Blumler \& E. Katz (Eds.), The Uses of Mass Communications: Current Perspectives on Gratifications Research, London: SAGE, pp.19-34.

Malik, M. R. \& Kiani, A. (2012). An Exploratory Study of Projection of Positive Image of Woman Through Media. Academic Research International, vol.2:2, p.651.

PakTribune (2007). Discussion Forums: Reseach Studies on Women and Media, Retrieved from http://paktribune.com/pforums/posts.php?t=5936\&start $=1$

Purnima (2011). Women's Issues in India. Role and Importance of Media, Global Media Journal, vol.4:1.

Salem, F., Mourtada, R., Al-Dabbagh, M., \& Gargani, G. H. A. L. I. A. (2011). The role of social media in Arab women's empowerment. The Arab Social Media Report.

Salinas, E. (2015). Changing Social Norms to Achieve Gender Equality: Expectations and Opportunities: Commission on the Status of Women.

Sial, S. (2009). Human Rights Reporting in Pakistani Media, Pakistan Institute of Peace Studies, vol.2:1. 
176 Role of Mass Media and Interpersonal Communication in Promoting Awareness about Woman

Rights in Pakistan

The Guardian (2015).Women's Rights Activists Use Social Media to Get their Message Out. Retrieved from http://www.theguardian.com/global-development/2015/mar/ 19/womens-rights-social-media-get-their-message-out

United Nation Human Rights (2014). Women's Rights Are Human Rights. New York and Geneva, 2014.

Lubna Zaheer is an Assistant Professor in the Institute of Communication Studies, University of the Punjab, Lahore.

Amber Mubeen is a Ph.D Scholar in the Institute of Communication Studies, University of the Punjab, Lahore. 